\author{
KAMIL SIKORA \\ ORCID: 0000-0003-4764-9782
}

Uniwersytet Marii Skłodowskiej-Curie w Lublinie

kamil.sikora@mail.umcs.pl

JERZY STELMASIAK

ORCID: 0000-0002-1397-3595

Uniwersytet Marii Skłodowskiej-Curie w Lublinie jerzy.stelmasiak@mail.umcs.pl

\title{
Związek powiatowo-gminny jako nowy model formy współpracy jednostek samorządu lokalnego
}

\begin{abstract}
Abstrakt: Od 2016 roku stało się możliwe tworzenie związków powiatowo-gminnych jako nowej formy współpracy jednostek samorządu lokalnego. Dotychczas prawnie dopuszczalnym było tworzenie związków w układzie tak zwanym poziomym, pomiędzy gminami - jako związków międzygminnych, pomiędzy powiatami jako związków powiatowych. Związki powiatowo-gminne są formą współpracy w układzie tak zwanym pionowym. Tym samym współpraca może się rozwijać nie tylko jak dotychczas horyzontalnie, lecz także w układzie wertykalnym między jednostkami gminnymi i powiatowymi. Procedura utworzenia związku powiatowo-gminnego jest analogiczna do procedury utworzenia związku powiatów z tym, że w postępowaniu w sprawie uzgodnienia projektu statutu związku powiatowo-gminnego powiaty i gminy zamierzające utworzyć związek reprezentuje starosta jednego z powiatów albo wójt jednej z gmin upoważniony przez starostów i wójtów pozostałych powiatów i gmin. Związek powiatowo-gminny stanowi formę organizacyjno-prawną wspólnego wykonywania zdań publicznych przez powiaty i gminy. Związek wykonuje zadania publiczne w imieniu własnym i na własną odpowiedzialność, posiada osobowość prawną, może występować jako samodzielny podmiot praw i obowiązków w obrocie prawnym. Do końca marca 2021 roku zostało zarejestrowanych w sumie trzynaście związków powiatowo-gminnych.
\end{abstract}

Słowa kluczowe: związek powiatowo-gminny, rejestr związków powiatowo-gminnych, statut związku powiatowo-gminnego, zadania związku powiatowo-gminnego gmina jako jednostka samorządu terytorialnego, powiat jako jednostka samorządu terytorialnego. 


\section{Wprowadzenie}

Odkąd w 1990 roku doszło do odrodzenia się w III RP samorządu terytorialnego na poziomie gminnym (ustawa $\mathrm{z}$ dnia 8 marca 1990 roku o samorządzie gminnym ${ }^{1}$ ), a następnie rozbudowy jego struktur o poziom samorządu powiatowego (ustawa $\mathrm{z}$ dnia 5 czerwca 1998 roku o samorządzie powiatowym ${ }^{2}$ ) i poziom samorządu województwa (ustawa z dnia 5 czerwca 1998 roku o samorządzie województwa ${ }^{3}$ ) jako jeden $z$ efektów reformy administracji publicznej zrealizowanej w 1998 roku, ustawodawca przewidział możliwość współpracy jednostek samorządu terytorialnego przy realizacji zadań publicznych. Od samego początku jedną z najbardziej rozpowszechnionych była forma związku, który mogły zawiązywać w pierwszej kolejności gminy (przepisy rozdziału 7 ustawy o samorządzie gminnym), a która następnie znalazła odzwierciedlenie także na poziomie samorządu powiatowego (przepisy rozdziału 7 ustawy o samorządzie powiatowym). Tworzenie związków międzygminnych lub międzypowiatowych miało zatem miejsce jedynie w ramach danego poziomu samorządu lokalnego.

$\mathrm{Z}$ dniem 1 stycznia 2016 roku zaczął obowiązywać przepis art. 72a ustawy o samorządzie powiatowym dodany przez art. 20 pkt 12 ustawy z dnia 25 czerwca 2015 roku o zmianie ustawy o samorządzie gminnym oraz niektórych innych ustaw ${ }^{4}$. Na jego podstawie stało się możliwe tworzenie związków powiatów z gminami, czyli związków powiatowo-gminnych, zatem nowej formy współpracy w ,pionowym układzie” między jednostkami samorządu terytorialnego. Natomiast $\mathrm{w}$ ustawie o samorządzie gminnym pojawił się przepis art. $73 \mathrm{~b}$ ustawy o samorządzie gminnym dodany przez art. 1 pkt 10 powyższej ustawy, na mocy którego możliwym jest przystąpienie powiatu do związku międzygminnego, co oznacza przekształcenie tegoż związku w związek powiatowo-gminny. Ustawodawca uznał za dopuszczalne wspólne wykonywanie zadań publicznych, w tym wydawanie decyzji w indywidualnych sprawach z zakresu administracji publicznej. Taki związek mógł również zostać utworzony celem zapewnienia wspólnej obsługi, w szczególności administracyjnej, finansowej i organizacyjnej: 1) jednostkom organizacyjnym gminy zaliczanym do sektora finansów publicznych, 2) gminnym instytucjom kultury, 3) innym zaliczanym do sektora finansów publicznych gminnym osobom prawnym utworzonym na podstawie odrębnych ustaw w celu wykonywania zadań publicznych, z wyłączeniem przedsiębiorstw, instytutów badawczych, banków i spółek prawa handlowego, na podstawie przepisu art. 6 i art. 10a ustawy o samorządzie gminnym. Jednoznacznie ustawodawca

\footnotetext{
1 Tekst pierwotny: Dz.U. Nr 16, poz. 95, tekst jedn. Dz.U. z 2020 r. poz. 713 ze zm.

2 Tekst pierwotny: Dz.U. Nr 91, poz. 578, tekst jedn. Dz.U. z 2020 r. poz. 920 ze zm.

3 Tekst pierwotny: Dz.U. Nr 91, poz. 576, tekst jedn. Dz.U. z 2020 r. poz. 1378 ze zm.

4 Dz.U. z 2015 r. poz. 1045.
} 
wskazał na wiodący celowy charakter i status tego nowego typu związku, a ciężar normatywnej regulacji w tym zakresie zawarł w przepisach ustawy o samorządzie powiatowym ${ }^{5}$, gdyż w ustawie o samorządzie gminnym ustawodawca poświęcił tej problematyce tylko przepis art. 73b, odsyłając do odpowiedniego stosowania przepisów ustawy o samorząazie powiatowym.

Obowiązujące do dnia 1 stycznia 2016 roku rozwiązania prawne pozwalały jedynie na tworzenie związków ograniczających się do tego samego poziomu jednostek samorządu terytorialnego przy równoczesnym ograniczeniu przedmiotowym realizowanych zadań publicznych do zadań rodzajowo tożsamych. Dopuszczalna była możliwość zainicjowania współpracy związku międzygminnego $\mathrm{z}$ powiatem, lecz jedynie $\mathrm{w}$ drodze zawarcia porozumienia na podstawie przepisu art. 64 ust. $5 \mathrm{w}$ zw. z art. 8 ust. 2 a ustawy o samorządzie gminnym. Naczelny Sąd Administracyjny w wyroku z dnia 20 stycznia 2015 roku $^{6}$ słusznie orzekł, że skoro art. 5 ust. 1 ustawy o samorządzie powiatowym dopuszcza zawieranie przez powiat porozumień $\mathrm{z}$ gminą $\mathrm{w}$ sprawie powierzenia jej prowadzenia zadań publicznych powiatu i jednocześnie ustawodawca w przepisach ustawy o samorządzie gminnym przewiduje możliwość zawierania takich porozumień między tymi jednostkami samorządowymi, to na podstawie art. 8 ust. $5 \mathrm{w} \mathrm{zw} . \mathrm{z}$ ust. $2 \mathrm{a}$ ustawy o samorządzie gminnym uzasadnione wydaje się ,zastąpienie” gminy przez związek międzygminny jako strony porozumienia zawartego z powiatem w celu przejęcia zadań powiatu o zasięgu terytorialnym obejmującym jedynie część powiatu ${ }^{7}$.

\section{Koncepcja prawna nowego modelu związku powiatowo-gminnego}

Wprowadzone od 1 stycznia 2016 roku rozwiązania prawne przyniosły w tym zakresie istotne zmiany, pozwoliły bowiem na współpracę gmin i powiatów w ramach formy związku będącego odrębną osobą prawną. Tym samym współpraca mogła się rozwijać nie tylko jak dotychczas w układzie horyzontalnym, lecz także w układzie pionowym między jednostkami gminnymi i powiatowymi ${ }^{8}$. Jak wska-

5 P. Lisowski, Nowe typy związków samorządowych w Polsce na przykładzie związków powiatowo-gminnych, [w:] Sposoby realizacji zadań publicznych, red. B. Dolnicki, Warszawa 2018, s. 421.

6 Sygn. II GSK 2100/13, LEX nr 1655772.

7 Por. wyrok Wojewódzkiego Sądu Administracyjnego w Rzeszowie z dnia 11 lutego 2020 roku, sygn. I SA/Rz 915/19, LEX nr 2783161.

8 R. Cybulska, Komentarz do art. 72 a u.s.p., [w:] Ustawa o samorzadzie powiatowym. Komentarz, red. B. Dolnicki, Warszawa 2020, s. 851. 
zano w uzasadnieniu projektu ustawy nowelizującej ${ }^{9}$, charakter zadań publicznych niejednokrotnie wykraczających poza zakres właściwości danego poziomu jednostki samorządu terytorialnego wymaga stworzenia ram prawnoorganizacyjnych dla możliwości ich wykonywania, w szczególności wspólnie przez gminy i powiaty. Związki gminno-powiatowe miały w założeniu wnioskodawców realizować zadania komplementarne na szczeblu gminnym i powiatowym. Założono też, że mechanizm funkcjonowania związku powiatowo-gminnego będzie identyczny z istniejącymi rozwiązaniami dotyczącymi związków międzygminnych i związków powiatów. Tworzące związek jednostki samorządu terytorialnego będą mogły przekazywać do realizacji na rzecz związku określone w statucie zadania publiczne (w tym wydawanie decyzji administracyjnych), a powstały związek będzie wykonywał te zadania w imieniu własnym i na własną odpowiedzialność. Szczegółowe określenie zakresu zadań realizowanych przez związek następuje $\mathrm{w}$ statucie związku uzgadnianym $\mathrm{z}$ wojewodą. Zadania gminne miały być realizowane na obszarze gmin członków, natomiast zadania powiatowe w zależności od uregulowań prawnych przyjętych w statucie - na terytorium albo gmin członkowskich, albo wszystkich gmin w powiecie. Powiat jako członek związku miał decydować o tym, czy przekazuje do związku całość zadania, czy też jedynie jego część w aspekcie terytorialnym. Wnioskodawcy dopuścili również możliwość przystępowania do obecnie funkcjonujących związków. Wskazano wprost, że powiat może przystąpić do związku międzygminnego, a gmina do związku powiatów. W takim przypadku następuje przekształcenie związku międzygminnego (powiatów) w związek powiatowo-gminny.

Wyłącznymi członkami związku powiatowo-gminnego mogą być powiaty i gminy. W przypadku gmin dotyczy to także miast na prawach powiatu czyli gmin, które realizują zadania publiczne o znaczeniu lokalnym z poziomu gminnego i powiatowego.

Jednakże należy podkreślić, że takiego miasta nie można traktować jako odmiennej od gminy jednostki samorządu terytorialnego, zatem mając powyższe na uwadze stronami (uczestnikami) związku powiatowo-gminnego mogą być wyłącznie powiaty oraz gminy miejskie, gminy wiejskie, gminy miejsko-wiejskie i miasta na prawach powiatu ${ }^{10}$.

Jak słusznie zauważa Piotr Lisowski, ustawodawca przewidział dwie możliwości kreowania związku powiatowo-gminnego. Po pierwsze, od razu jako związek tworzony przez powiaty z gminami, o czym świadczy treść art. 72a ust. 1 ustawy o samorządzie powiatowym. Po drugie, przez przystąpienie gminy do związku powiatów, co wynika z przepisu art. 73 b ustawy o samorządzie gminnym i art. $72 \mathrm{c}$ ust. 1 ustawy o samorządzie powiatowym. W tym drugim przypadku punktem wyjścia może być związek międzygminny lub związek powiatów, do

${ }^{9}$ Sejm RP VII kadencji, druk nr 2656.

10 A. Kasina, Komentarz do art. 72a u.s.p., [w:] Ustawa o samorzadzie powiatowym. Komentarz, red. P. Drembkowski, Legalis 2019. 
którego to związku przystępuje odpowiednio powiat lub gmina, co skutkuje przekształceniem w związek powiatowo-gminny ${ }^{11}$.

Procedura utworzenia związku powiatowo-gminnego jest analogiczna do procedury utworzenia związku powiatów, $\mathrm{z}$ tym że w postępowaniu $\mathrm{w}$ sprawie uzgodnienia projektu statutu związku powiatowo-gminnego powiaty i gminy zamierzające utworzyć związek reprezentuje starosta jednego z powiatów albo wójt jednej z gmin upoważniony przez starostów i wójtów pozostałych powiatów i gmin. Zasady reprezentacji jednostek w związku określa statut związku ${ }^{12}$.

Od samego początku oczywistym było pytanie, jakie zadania publiczne o znaczeniu lokalnym powiaty i gminy mogą realizować wspólnie. Sąd Najwyższy w wyroku z dnia 6 maja 2011 roku orzekł, że

związek - z woli zrzeszonych w nim gmin — wyręcza je w realizacji powierzonych mu zadań. Jego pozycja, oceniana pod kątem przedmiotu działalności, nie jest więc odmienna od pozycji zrzeszonych gmin; nie jest on też jednostką wyspecjalizowaną, zawodowo trudniącą się wykonywaniem powierzonych zadań, lecz organizacją gmin umożliwiającą im połączenie sił w celu łatwiejszego i o większej skali zaspokajania zbiorowych potrzeb wspólnot gminnych ${ }^{13}$.

Podkreślić należy, że związki umożliwiają efektywniejszą realizację zadania publicznego, ponadto generują niższe koszty aniżeli w sytuacji jednostkowego działania gminy lub powiatu. Wyraźne rozdzielenie zadań i kompetencji należących do gmin i powiatów czyni uzasadnionym spostrzeżenie, iż można jedynie mówić o wspólnych dziedzinach zadań realizowanych przez gminy i powiaty. Usprawiedliwionym jest pogląd, że w przypadku związków powiatowo-gminnych chodzi o wykonywanie zadań wspólnie się uzupełniających w danym zakresie przedmiotowym, czyli komplementarnych. Elastyczność tej formy współpracy powiatowo-gminnej pozwala dostosować się do uwarunkowań i potrzeb lokalnych ${ }^{14}$. Podczas analizy potencjalnych możliwości współpracy na plan pierwszy wysuwają się zadania dotyczące organizowania transportu zbiorowego w ramach granic administracyjnych gmin i powiatów tworzących związek, ochrony środowiska, rozwoju turystycznego, a także oświaty.

Związek powiatowo-gminny stanowi formę organizacyjno-prawną wspólnego wykonywania zdań publicznych przez powiaty i gminy. Związek taki wykonuje zadania publiczne w imieniu własnym i na własną odpowiedzialność. Ponadto posiada osobowość prawną. W związku z tym może występować jako samodzielny podmiot praw i obowiązków w obrocie prawnym. Wyposażenie podmiotu $\mathrm{W}$ osobowość prawną skutkuje uzyskaniem przez ten podmiot zdolności bycia podmiotem w zakresie praw i obowiązków, a także uzyskaniem zdolności

11 P. Lisowski, op. cit., s. 421; zob. także B. Jaworska-Dębska, Samorząd terytorialny, [w:] Prawo administracyjne. Pojęcia. Instytucje. Zasady w teorii i orzecznictwie, red. M. Stahl, Warszawa 2019, s. 513.

12 R. Cybulska, op. cit., s. 851.

13 Sygn. II CSK 409/10, LEX nr 863960.

14 P. Lisowski, op. cit., s. 431. 
prawnej do realizacji tych praw i obowiązków. Należy nadmienić, że występuje nie tylko jako podmiot prawa prywatnego, ale też jako odrębny podmiot publicznoprawny. Osobowość publicznoprawna pozwala związkowi na podejmowanie między innymi władczych działań administracji publicznej, które zmierzać będą do realizacji zadań publicznych. Dniem nabycia osobowości prawnej przez związek jest dzień ogłoszenia jego statutu w wojewódzkim dzienniku urzędowym. Podejmowane są wówczas wyłącznie te czynności, które mają doprowadzić do jego utworzenia jako osoby prawnej.

Prowadzenie rejestru związków powiatowo-gminnych powierzono ministrowi właściwemu do spraw administracji publicznej. Rejestr związków powiatowo-gminnych jest jawny, a szczegółowe kwestie związane między innymi z ich rejestracją reguluje rozporządzenie Ministra Spraw Wewnętrznych i Administracji z dnia 21 grudnia 2015 roku w sprawie rejestru związków powiatowo-gminnych oraz ogłaszania statutów związków i ich zmian ${ }^{15}$. Rejestr jest prowadzony w formie elektronicznej i składa się z następujących informacji:

1. kolejny numer związku powiatowo-gminnego w rejestrze;

2. nazwa związku powiatowo-gminnego i jego siedziba;

3. oznaczenie powiatów i gmin uczestniczących w związku powiatowo-gminnym;

4. zadania związku powiatowo-gminnego;

5. czas trwania związku powiatowo-gminnego;

6. data rejestracji związku powiatowo-gminnego;

7. data ogłoszenia statutu związku powiatowo-gminnego oraz jego zmian;

8. data likwidacji albo przekształcenia związku powiatowo-gminnego.

Minister właściwy do spraw administracji publicznej jest zobowiązany dokonać wpisu do rejestru w terminie 14 dni od dnia otrzymania zgłoszenia wojewody. Ustalony w powyższym rozporządzeniu termin ma charakter instrukcyjny, a jego ewentualne niezachowanie przez ministra nie rodzi żadnych sankcji prawnych. Postępowanie w przedmiocie wpisu do rejestru związków powiatowo-gminnych rozpoczyna się od poinformowania wojewody właściwego ze względu na siedzibę związku przez starostę albo wójta (burmistrza/prezydenta miasta). Informacja powinna zawierać oznaczenie uchwał rad powiatów i rad gmin o utworzeniu związku powiatowo-gminnego oraz o przyjęciu jego statutu. Ponadto do informacji należy dołączyć wyciągi z protokołów posiedzeń rad powiatów i rad gmin w części dotyczącej trybu podejmowania uchwał, o których mowa wyżej. Wojewoda, w terminie 30 dni od dnia otrzymania od starosty albo wójta wskazanej informacji, przekazuje do organu prowadzącego rejestr - ministra właściwego do spraw administracji publicznej — zgłoszenie w sprawie rejestracji związku powiatowo-gminnego. O wpisie do rejestru związku powia-

15 Dz.U. z 2015 r. poz. 2282. 
towo-gminnego minister właściwy do spraw administracji publicznej powiadamia właściwego wojewodę, starostę, wójta oraz właściwą miejscowo regionalną izbę obrachunkową. Powiadomienie powinno być zgłoszone w terminie $7 \mathrm{dni}$ od dnia dokonania wpisu w rejestrze.

Należy podkreślić, że przystąpienie do związku gminy powoduje jego przekształcenie w związek powiatowo-gminny, lecz jest to prawo gminy, a nie jej obowiązek. Ponadto obowiązek utworzenia związku musiałby bowiem wynikać wprost z przepisu ustawy, tak jak ma to miejsce w sytuacji uregulowanej w art. 64 ust. 4 ustawy o samorządzie gminnym. Przepis ten stanowi, że obowiązek utworzenia związku może być nałożony tylko w drodze ustawy, która określa zadania związku i tryb zatwierdzenia jego statutu. Jak słusznie zauważa Renata Cybulska:

przekształcenie związku powiatów lub związku międzygminnego w związek powiatowo-gminny pociąga za sobą obowiązek zmiany statutu związku z odpowiednim zastosowaniem przepisów dotyczących związku powiatów, albo związku międzygminnego. Zmiana statutu będzie dotyczyła nie tylko wskazania gminy jako nowego członka związku, ale także zasad reprezentacji jednostek samorządu terytorialnego czy też nowych zadań, jeśli takie są przewidziane po przystąpieniu gminy do już istniejącego związku ${ }^{16}$.

Po przekształceniu związku gminnego w nowopowstały związek powiatowo-gminny, z dniem ogłoszenia jego statutu wstępuje we wszystkie prawa i obowiązki przekształconego związku. Staje się zatem następcą prawnym, z tym zastrzeżeniem ustawowym, że ujawnienie w księgach wieczystych lub w rejestrach sukcesji na związek powiatowo-gminny praw w nich ujawnionych następuje na wniosek związku ${ }^{17}$.

Jeżeli chodzi o zmianę statutu związku powiatów, należy odnieść się do art. 67 a ustawy o samorządzie powiatowym, który w ust. 1 stanowi, że zmiany statutu związku dokonuje zgromadzenie związku w formie uchwały (w tym zakresie przepisy art. 67 ust. 1a i 1b ustawy o samorządzie powiatowym stosuje się odpowiednio). Ponadto zmiana statutu związku podlega ogłoszeniu w wojewódzkim dzienniku urzędowym. Zmiana statutu związku międzygminnego uregulowana została $\mathrm{w}$ art. 67 a ustawy o samorządzie gminnym i zawiera tożsame regulacje z powołanym w tym zakresie przepisem. Z racji przyznanego organom związku powiatów oraz organom związku międzygminnego kompetencji do wydawania decyzji administracyjnych, organy nowo powstałego związku powiatowo-gminnego stają się organami właściwymi lub stronami wszczętych i niezakończonych postępowań administracyjnych i sądowych. Co prawda ustawodawca nie wskazał wprost, z jakim dniem następuje ,wstąpienie” organów związku powiatowo-gminnego właściwych do rozstrzygania spraw w postępowaniu administracyjnym bądź udziału w postępowaniach sądowych, jednak należy przyjąć, że terminem tym

16 R. Cybulska, op. cit., s. 851.

17 R. Cybulska, Komentarz do art. 73 b u.s.g., [w:] Ustawa o samorzadzie gminnym..., red. B. Dolnicki, s. 859. 
powinien być dzień ogłoszenia statutu związku w wojewódzkim dzienniku urzędowym (z tą chwilą bowiem - jak już wskazano — związek powiatowo-gminny wstępuje we wszystkie prawa i obowiązki przekształconego związku, czy to powiatowego, czy też międzygminnego).

\section{Rodzaje zarejestrowanych związków powiatowo-gminnych}

W ciągu ostatnich pięciu lat obowiązywania regulacji prawnych dopuszczających funkcjonowanie związków powiatowo-gminnych zauważalne jest zainteresowanie tą formą jednostek samorządu terytorialnego. Do końca marca 2021 roku zostało zarejestrowanych $\mathrm{w}$ sumie trzynaście związków powiatowo-gminnych. Największa liczba rejestracji miała miejsce w 2016 roku, czyli wraz z początkiem obowiązywania przedmiotowych regulacji, kiedy to zarejestrowano aż pięć związków. Pierwszym był związek o nazwie „JEDŹ Z NAMI” z siedzibą w Strzelcach Opolskich (woj. opolskie), którego rejestracja miała miejsce dnia 31 maja 2016 roku. Ponadto do końca 2016 roku zarejestrowano jeszcze Zielonogórski Związek Powiatowo-Gminny z siedzibą w Czerwieńsku (woj. lubuskie); Związek Powiatowo-Gminny Powiatu Świdwińskiego z siedzibą w Świdwinie (woj. zachodniopomorskie); Krośnieński Związek Powiatowo-Gminny z siedzibą w Krośnie Odrzańskim (woj. lubuskie); Związek Powiatowo-Gminny „Sejmik Średzki” z siedzibą w Środzie Wielkopolskiej (woj. wielkopolskie). W kolejnych latach obowiązywania przepisów dotyczących związków powiatowo-gminnych liczba nowo tworzonych związków nie była już tak imponującą, gdyż w 2017 roku zarejestrowano trzy nowe związki: Beskidzki Związek Powiatowo-Gminny z siedzibą w Bielsku-Białej (woj. śląskie); Powiatowo-Gminny Związek Komunikacyjny z siedzibą w Jaśle (woj. podkarpackie); Związek Powiatowo-Gminny Powiatu Żagańskiego z siedzibą w Żaganiu (woj. lubuskie). Następnie już w 2019 roku zarejestrowano trzy kolejne związki: Człuchowski Związek Powiatowo-Gminny z siedzibą w Człuchowie (woj. pomorskie); Oławskie Przewozy Gminno-Powiatowe z siedzibą w Oławie; „Ziemia Lubaczowska” z siedzibą w mieście Lubaczowie (woj. podkarpackie). Natomiast w 2020 roku doszło do rejestracji jedynie dwóch nowych — Związku Zachodniopomorskiej Strefy Centralnej z siedzibą w Drawsku Pomorskim (woj. zachodniopomorskie) oraz Związku Gmin i Powiatów Kanału Elbląskiego i Pojezierza Iławskiego z siedzibą w Ostródzie (woj. warmińsko-mazurskie). 
Tabela 1. Związki powiatowo-gminne w RP

\begin{tabular}{|l|c|}
\hline \multicolumn{1}{|c|}{ Nazwa województwa } & $\begin{array}{c}\text { Liczba zarejestrowanych związków } \\
\text { powiatowo-gminnych do 31 marca 2021 roku }\end{array}$ \\
\hline województwo mazowieckie & $\mathbf{1}$ \\
\hline województwo wielkopolskie & $\mathbf{1}$ \\
\hline województwo lubelskie & $\mathbf{2}$ \\
\hline województwo warmińsko-mazurskie & $\mathbf{1}$ \\
\hline województwo zachodniopomorskie & $\mathbf{1}$ \\
\hline województwo podlaskie & \\
\hline województwo dolnośląskie & $\mathbf{2}$ \\
\hline województwo pomorskie & \\
\hline województwo łódzkie & $\mathbf{3}$ \\
\hline województwo kujawsko-pomorskie & $\mathbf{1}$ \\
\hline województwo podkarpackie & $\mathbf{1}$ \\
\hline województwo małopolskie & \\
\hline województwo lubuskie & \\
\hline województwo śląskie & \\
\hline województwo świętokrzyskie & \\
\hline województwo opolskie & \\
\hline
\end{tabular}

Źródło: opracowanie własne na postawie wykazu związków powiatowo-gminnych, www.gov.pl/web/ mswia/zarejestruj-zmien-statut-lub-wyrejestruj-zwiazek-miedzygminny-zwiazek-powiatow-zwiazek-powiatowo-gminny (dostęp: 31.03.2021).

Oznacza to, że „przodują” trzy województwa: lubuskie, zachodniopomorskie i podkarpackie. W sumie na 16 województw ponad w połowie doszło do powstania choćby jednego związku powiatowo-gminnego, natomiast w siedmiu województwach - mazowieckim, lubelskim, podlaskim, łódzkim, kujawsko-pomorskim, małopolskim i świętokrzyskim — do chwili obecnej nie dokonano rejestracji żadnego związku powiatowo-gminnego.

Tabela 2. Analiza zadań realizowanych przez funkcjonujące związki powiatowo-gminne

\begin{tabular}{|l|c|}
\hline \multicolumn{1}{|c|}{ Zadanie realizowane przez związek powiatowo-gminny } & $\begin{array}{c}\text { Liczba związków realizujących } \\
\text { zadanie publiczne }\end{array}$ \\
\hline Organizacja i rozwój publicznego transportu zbiorowego & 9 \\
\hline $\begin{array}{l}\text { promocja walorów przyrodniczo-kulturowych, rozwój } \\
\text { turystyki i działalność proekologiczna }\end{array}$ & 1 \\
\hline $\begin{array}{l}\text { zapewnienie wspólnej obsługi jednostek organizacyjnych } \\
\text { powiatu i gminy zaliczanych do sektora finansów publicz- } \\
\text { nych i instytucji kultury, aktywizacja lokalnego rynku pracy }\end{array}$ & 3 \\
\hline
\end{tabular}

Źródło: opracowanie własne na postawie wykazu związków powiatowo-gminnych, www.gov.pl/web/ mswia/zarejestruj-zmien-statut-lub-wyrejestruj-zwiazek-miedzygminny-zwiazek-powiatow-zwiazek-powiatowo-gminny (dostęp: 31.03.2021). 
Pod względem organizacyjnym zdecydowanie dominuje model współpracy jednego powiatu z jedną lub kilkoma gminami, ponieważ taki model organizacyjno-prawny obowiązuje w aż 9 z 11 związków powiatowo-gminnych. Jedynie w dwóch związkach powstałych w 2020 roku zastosowano model współpracy odpowiednio dwóch - Związek Zachodniopomorskiej Strefy Centralnej z siedzibą w Drawsku Pomorskim (woj. zachodniopomorskie) — oraz trzech powiatów - Związek Gmin i Powiatów Kanału Elbląskiego i Pojezierza Iławskiego z siedzibą w Ostródzie (woj. warmińsko-mazurskie) — z kilkunastoma gminami. We wszystkich trzynastu związkach powiatowo-gminnych czas ich trwania jest nieoznaczony.

\section{Zakończenie}

Analiza i ocena z perspektywy pięciu lat obowiązywania regulacji prawnych umożliwiających powstawanie związków powiatowo-gminnych lub przekształcania dotychczasowych związków międzygminnych, bądź związków powiatów w związki powiatowo-gminne pozwala stwierdzić, że spełniają swoją rolę. Ponadto największą ilość związków utworzono wraz z początkiem obowiązywania przedmiotowych podstaw prawnych, a ich obecna ilość wynosząca trzynaście związków nie jest może imponująca, gdy porównamy ją do liczby funkcjonujących związków międzygminnych, których jest obecnie $314^{18}$, lecz na tle jedynie siedmiu zarejestrowanych związków powiatów wygląda wręcz imponująco. Oznaczać to może tylko jedno: brakowało prawnej formy współpracy między samorządem powiatowym a gminnym. Ponadto organy samorządów powiatowych zauważają szereg korzyści płynących ze wspólnego wykonywania zadań z gminami wchodzącymi w skład danego powiatu, a nie tylko z sąsiednimi powiatami. Działalność obecnych związków powiatowo-gminnych zdominowana została przez realizację zadania publicznego dotyczącego organizacji transportu zbiorowego co również nie może dziwić, gdyż zapewnienie efektywnego i skutecznie funkcjonującego transportu zbiorowego jest jednym z ważniejszych zadań samorządowych. Jest to przy tym jedno z kosztowniejszych zadań publicznych, natomiast współpraca w tym zakresie może się przyczynić do ograniczenia kosztów wykonywanego zadania z korzyścią dla wszystkich jednostek samorządu terytorialnego, a tym samych mieszkańców wspólnot. Także zadania z zakresu rozwoju regionalnego, turystyki i ochrony środowiska są najczęściej celem utworzenia związku powiatowo-gminnego, oprócz transportu. Dlatego też związki powiatowo-gminne są

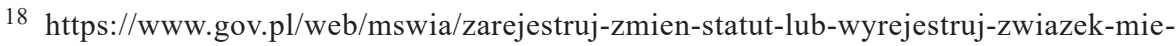
dzygminny-zwiazek-powiatow-zwiazek-powiatowo-gminny (dostęp: 31.03.2021). 
atrakcyjną formą współpracy między jednostkami samorządu lokalnego, ponieważ pozwalają na optymalne wykorzystanie potencjału powiatowego i gminnego z korzyścią dla mieszkańców lokalnych wspólnot samorządowych.

\section{Bibliografia}

\section{Akty prawne}

Ustawa z dnia 8 marca 1990 roku o samorządzie gminnym, tekst pierwotny: Dz.U. Nr 16, poz. 95, tekst jedn. Dz.U. z 2020 r. poz. 713 ze zm.

Ustawa z dnia 5 czerwca 1998 roku o samorządzie powiatowym, tekst pierwotny: Dz.U. Nr 91, poz. 578 , tekst jedn. Dz.U. z 2020 r. poz. 920 ze zm.

Ustawa z dnia 5 czerwca 1998 roku o samorządzie województwa, tekst pierwotny: Dz.U. Nr 91, poz. 576, tekst jedn. Dz.U. z 2020 r. poz. 1378 ze zm.

Ustawa z dnia 25 czerwca 2015 roku o zmianie ustawy o samorządzie gminnym oraz niektórych innych ustaw, Dz.U. z 2015 r. poz. 1045.

Rozporządzenie Ministra Spraw Wewnętrznych i Administracji z dnia 21 grudnia 2015 roku w sprawie rejestru związków powiatowo-gminnych oraz ogłaszania statutów związków i ich zmian, Dz.U. z 2015 r. poz. 2282.

\section{Orzecznictwo}

Wyrok Sądu Najwyższego z dnia 6 maja 2011 roku, sygn. II CSK 409/10, LEX nr 863960.

Wyrok Naczelnego Sądu Administracyjnego z dnia 20 stycznia 2015 roku, sygn. II GSK 2100/13, LEX nr 1655772.

Wyrok Wojewódzkiego Sądu Administracyjnego w Rzeszowie z dnia 11 lutego 2020 roku, sygn. I SA/Rz 915/19, LEX nr 2783161.

\section{Literatura}

Cybulska R., Komentarz do art. 72 a u.s.p., [w:] Ustawa o samorzadzie powiatowym. Komentarz, red. B. Dolnicki, Warszawa 2020.

Cybulska R., Komentarz do art. 73 b u.s.g., [w:] Ustawa o samorzadzie gminnym. Komentarz, red. B. Dolnicki, Warszawa 2020.

Jaworska-Dębska B., Samorząd terytorialny, [w:] Prawo administracyjne. Pojęcia. Instytucje. Zasady w teorii i orzecznictwie, red. M. Stahl, Warszawa 2019.

Kasina A, Komentarz do art. 72 a u.s.p., [w:] Ustawa o samorzadzie powiatowym. Komentarz, red. P. Drembkowski, Legalis 2019.

Lisowski P., Nowe typy zwiazków samorzadowych w Polsce na przykladzie zwiazków powiatowo-gminnych, [w:] Sposoby realizacji zadań publicznych, red. B. Dolnicki, Warszawa 2018. 


\title{
Poviat and Commune Union as a New Model of Cooperation Form Between Local Government Units
}

\begin{abstract}
Summary
Since 2016, it has become possible to create poviat and commune unions as a new form of cooperation between local government units. Until now, it was legally permissible to create unions in the so-called horizontal, between communes - as inter-communal unions, between poviats as poviat unions. Poviat and commune unions are a form of cooperation in the so-called vertical. Thus, cooperation may develop not only horizontally, but also vertically between commune and poviat units. The procedure for establishing a poviat-commune union is analogous to the procedure for establishing a poviat-commune union, except that in the procedure for agreeing the draft statute of a poviat-commune union, poviats and communes intending to establish a union are represented by the starost of one of the poviats or the head of one from among the communes authorized by starosts and voices of the remaining counties and communes. A poviat and commune union is an organizational and legal form of joint performance of public tasks by poviats and communes. The union performs public tasks on its own behalf and under its own responsibility, has legal personality, and may act as an independent subject of rights and obligations in legal transactions. By the end of March 2021, a total of 13 poviat and commune associations were registered.
\end{abstract}

Keywords: poviat and commune union, register of poviat and commune associations, statute of a poviat and commune union, tasks of a poviat and commune union, commune as a local government unit. 